\title{
Resolving the Issue of Artefact Deposition at Star Carr
}

\author{
By BARRY TAYLOR ${ }^{1}$, BEN ELLIOTT ${ }^{2}$, CHANTAL CONNELLER ${ }^{3}$, NICKY MILNER ${ }^{2}$, ALEX BAYLISS ${ }^{4}$, \\ BECKY KNIGHT $^{2}$, and MIKE BAMFORTH ${ }^{2}$
}

Since its publication in 1954 Star Carr has held an iconic status in British Mesolithic archaeology. The original excavations at the site recorded a large assemblage of bone and antler tools from a sequence of peat deposits at the edge of the Lake Flixton. Over 60 years later this remains the largest assemblage of bone and antler artefacts of its date in Britain and has been an invaluable source of information for life in the early Mesolithic. However, the interpretation of this material has been the subject of intense debate, and the assemblage has been variously described as the remains of an in situ settlement, a refuse dump, and the result of culturally prescribed acts of deposition. Fundamentally, these very different ideas of the nature of the site depend on differing interpretations of the environmental context into which the majority of the organic artefacts were deposited. This paper presents the results of recent work at Star Carr that helps to resolve the debate surrounding both the context of the assemblage and the motivations that lay behind its deposition.

Keywords: Star Carr, Lake Flixton, Mesolithic, deposition, material culture, environmental data, radiocarbon dating

Star Carr lies at the western end of the Lake Flixton, in the eastern Vale of Pickering (North Yorkshire, UK) (Fig. 1). Following the initial discovery of the site by John Moore, a programme of excavation and palaeoenvironmental analysis was carried out under the direction of Grahame Clark (Clark 1949; 1950; 1954). The excavations consisted of a series of trenches (referred to as cuttings) dug through the peat that had formed at the edge of the lake. Here Clark recorded an unprecedented range of organic material culture, including 191 barbed antler points and a suite of other objects including red deer antler frontlets, elk antler mattocks, bone scrapers, and awls. A large assemblage of red deer antler, much of which had been worked to produce the barbed points, was also recorded, along with animal bone and over 16,000 worked flints

\footnotetext{
${ }^{1}$ Department of History and Archaeology, University of Chester, Chester, CH1 4BJ UK

Email: b.taylor@chester.ac.uk

${ }^{2}$ Department of Archaeology, The King's Manor, University of York, YO1 7EP, UK

${ }^{3}$ Archaeology (SAHC), University of Manchester, Mansfield Cooper Building, Oxford Road, Manchester M13 9PL, UK

${ }^{4}$ Historic England, 1 Waterhouse Square, 138-42 Holborn, London, EC1N 2ST, UK
}

(Clark 1954, 96). Most of this material was associated with a deposit of birch 'brushwood' that Clark suggested had been deliberately laid down to act as a platform on which activity took place (ibid., 12).

\section{SUBSEQUENT FIELDWORK}

Between 1985 and 1992 further work was carried out at the site by the Vale of Pickering Research Trust (Cloutman \& Smith 1988; Mellars \& Dark 1998). Two trenches (VP85A \& B) were excavated through the lake edge deposits $c .20 \mathrm{~m}$ to the east of the area investigated by Clark (Fig. 2). During this work, part of a platform or trackway made from deliberately split willow or aspen timbers was recorded, along with a small assemblage of animal bone, worked antler and flint, and a series of test pits were also excavated on the higher ground above the lake shore, recording scatters of worked flint and poorly preserved animal bone (Mellars \& Dark 1998).

As part of this work two major palaeoenvironmental studies were carried out (Cloutman \& Smith 1988; Dark 1998). Both adopted a similar methodology, analysing samples at intervals through the lake edge deposits in order to model the spatial and chronological development of the local environments 


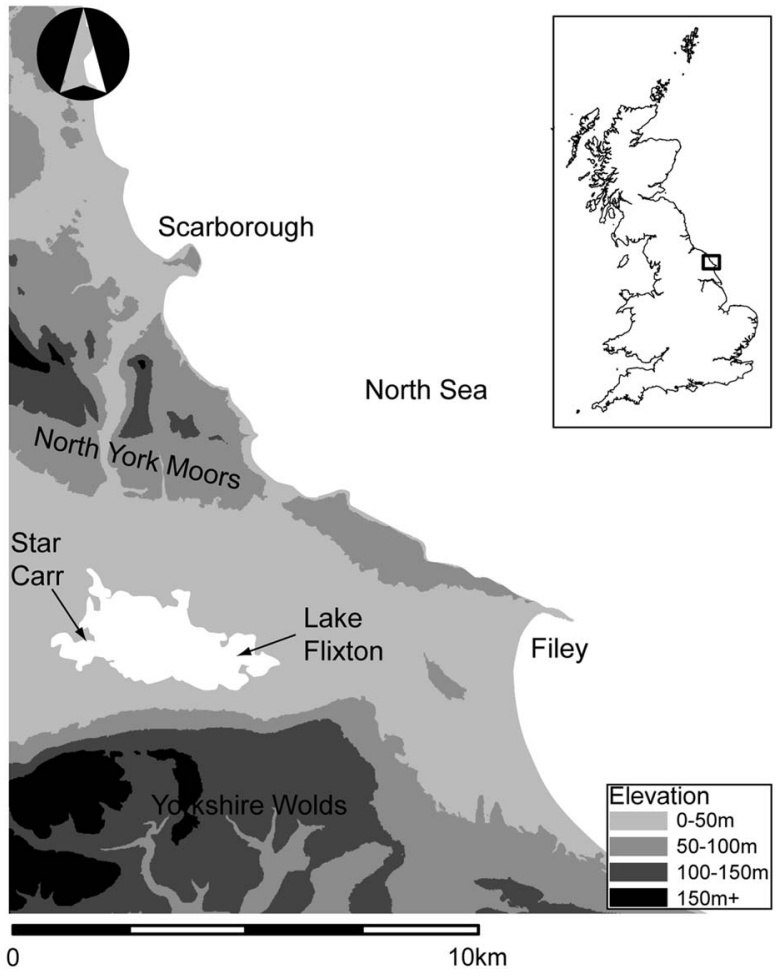

Fig. 1.

Location of Star Carr and Lake Flixton

(Fig. 2). The more recent of these (Dark 1998), employed higher resolution pollen analysis accompanied by plant macrofossil analysis and a more reliable radiocarbon chronology to produce the definitive account of the site's environmental history. This showed that the lake edge environment developed from reedswamp growing in standing water to fen and carr over a period of approximately 300 years. The development of the lake edge vegetation was also interrupted on at least two occasions by the deliberate burning of the reed beds, the first of which coincided with the construction of the timber platform recorded in Trench VP85A (ibid., 158).

This research also led to a revised chronology for the human occupation of Star Carr. Using evidence for burning recorded in the environmental profiles as a proxy for human activity, Dark et al. (2006, 188) argued that there were two main phases of activity; the first, starting at c. 8970 cal BC and lasting for approximately 80 years, the second starting at $c .8790$ cal $\mathrm{BC}$ and lasting approximately 130 years. Based on a comparison between the heights of some of the artefacts recorded by Clark and the levels at which the burning was recorded in the environmental profiles, Dark et al. argued that the first burning phase coincided with the main episode of artefact deposition, whilst smaller quantities of artefacts (including some of the barbed antler points) were deposited during the second phase (ibid., 190).

\section{CHANGING INTERPRETATION OF THE AREA INVESTIGATED BY CLARK}

The material recorded by Clark constitutes one of the largest assemblages of early Mesolithic bone and antler artefacts in western Europe, and has provided important insights into the nature of human society at this time. However, despite its importance, interpretations of this material remain contested, due largely to uncertainty regarding the nature of the environment into which the artefacts were deposited. In his initial interpretation of the site, Clark argued that the assemblage had been laid down within reedswamp at the edge of the lake (Clark 1954,12) and represented an area of in situ activity that took place upon the brushwood platform (ibid., 9). Thus, the various bone and antler artefacts, along with the worked flint, antlerworking waste, and animal bones represented the detritus of settlement, accumulating through a combination of accidental loss and casual disposal.

However, since the 1970s new interpretations regarding both the modes and contexts of artefact deposition at the site have been suggested. To begin with, several researchers have argued that the part of the site excavated by Clark would have been beneath the level of the lake at the time that occupation took place, making it an unsuitable area for habitation. Price $(1982$; 1983) noted that the bone and antler could only have been preserved if it had been deposited directly into standing water, a point that was supported by a lack of evidence for gnawing on the animal bones (Chatterton 2003, 70). Chatterton also argued that the presence of aquatic plant remains in the artefact bearing deposits indicated that the lake water was present as those deposits formed, and noted that estimates of the actual level of the lake based on the work carried out by Dark were higher than the surface topography in the area investigated by Clark. In addition, Price (1982) and Chatterton (2003, 69-70) have suggested that the brushwood platform was simply a natural accumulation of wood at the edge of the lake, noting in particular the lack of evidence of any structural component, covering, or 


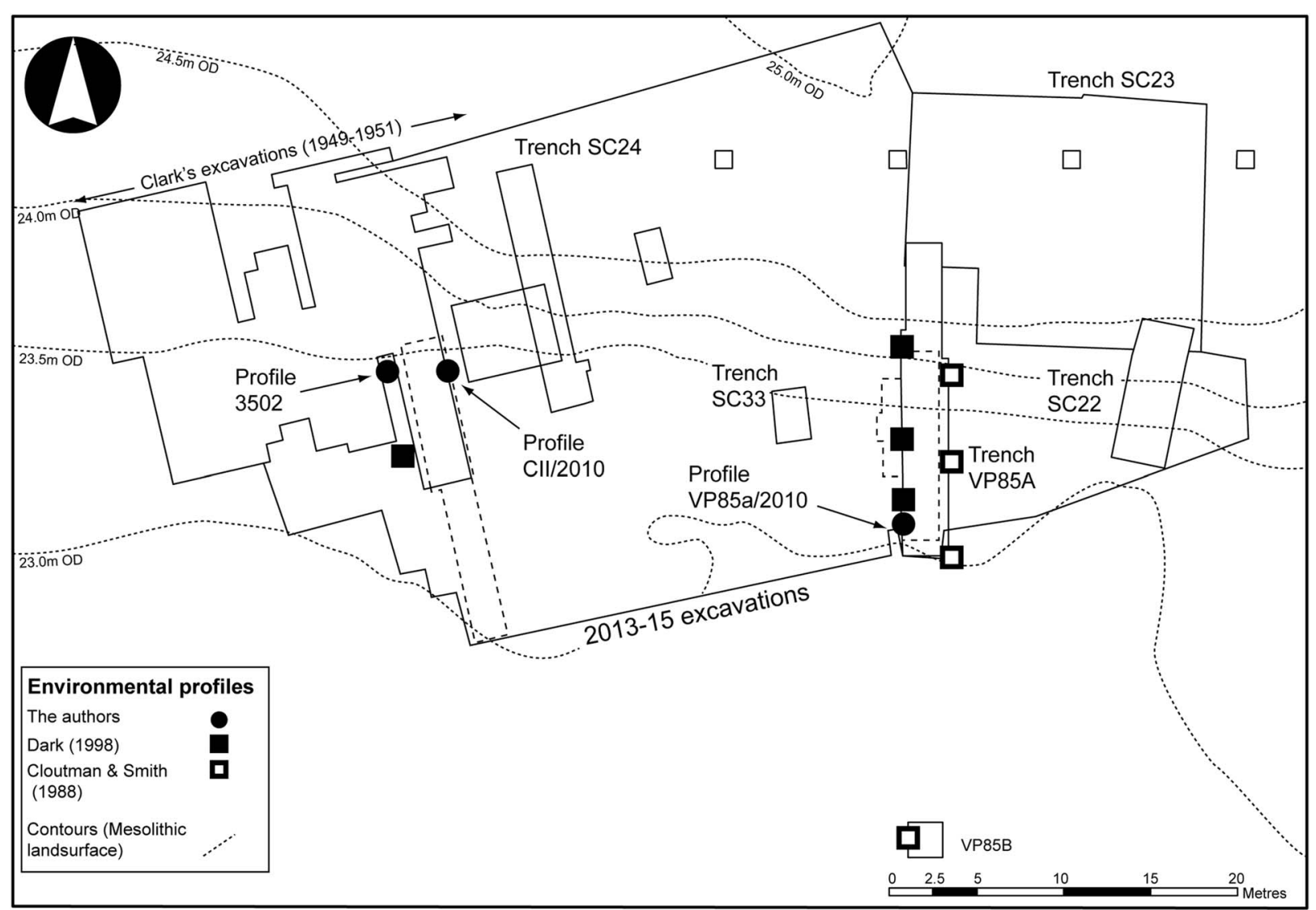

Fig. 2.

Excavated areas at Star Carr \& the location of environmental profiles mentioned in the text

associated hearths, and the apparently uninterrupted formation of peat over the woody layers.

This reassessment of the depositional context of the assemblage also led to new interpretations of the processes through which deposition occurred. Price (1983, $786)$ and Legge and Rowley-Conwy $(1998,12)$ argued that the assemblage had been deposited as waste from an area of activity on the adjacent lake shore. Other researchers have countered that the character of the assemblage indicates that deposition was more complex and deliberate than simple ad hoc disposal. Chatterton, for example, has argued that the presence of both intact and broken barbed points, as well as rare objects such as shale and amber beads, indicates that the assemblage was generated through 'deliberate and purposeful deposition', which may have formed part of ritual practices following a successful hunt (Chatterton 2003, 73, 78). Alternatively, Conneller (2004) has suggested deposition was particularly focused on artefacts made from red deer, which appear to have been spiritually important animals.
However, these re-interpretations have not been without their critics, and in recent years a robust defence of Clark's original thesis has been mounted by Mellars (Mellars \& Dark 1998; Mellars 2009). Dismissing the presence of aquatic plant material within the peat as the result of human or animal action, and pointing to alleged discrepancies in the topographic survey, Mellars argued that the area of occupation lay above the level of the lake, as Clark had originally suggested (Mellars 2009, 506). Furthermore, he noted that coverings of hides would not necessarily survive, despite the water-logged conditions, and that the brushwood platform may still have acted as an occupation surface (Mellars \& Dark 1998, 221). Finally, Mellars identified at least three areas of flint knapping within the area excavated by Clark, on the basis of the distribution of flint tools and debitage recorded during the original excavations This, he argued, indicated that the assemblage was being generated through in situ activity carried out on the brushwood platform, rather 
than as waste material discarded from an adjacent area (ibid., 220; Mellars 2009, 507-10).

More recently, Rowley-Conwy (2010) has re-interpreted the environmental data presented by Walker and Godwin (1954) to argue that the brushwood platform, and the material associated with it, lay within the zone of the seasonally fluctuating lake water level (Rowley-Conwy 2010, 279-81). As such, the area would have been dry enough to allow in situ activity during the summer months, when the site was inhabited, but would have been submerged during other times of the year. Alternatively, Taylor (2011, 78-80) has argued that the assemblage actually spans a range of environments based on the results of environmental analysis at other parts of the basin. By calculating a minimum level for the lake, he further argued that deposition began in shallow standing water close to the lake shore, but continued into increasingly more terrestrialised environments as the wetlands developed.

Unfortunately, it is not possible to resolve this debate using the existing data from the site. Despite the very detailed work carried out by Dark, it has proved difficult to tie the material recorded by Clark into the more recent environmental sequences due to the limited contextual and spatial information in the original publications. Attempts to determine whether the area investigated by Clark lay beneath the level of the lake have also proven problematic due to Mellars' assertion that the existing survey of the basal topography of the site is $0.3 \mathrm{~m}$ too low (Mellars 2009, 506). Furthermore, the method used to estimate the lake level cited by Chatterton (2003) and Mellars (2009) was based on the point at which aquatic plant macrofossils were no longer being deposited in the peat in one of Dark's environmental profiles, which does not necessary reflect the level of the lake (see Taylor 2011, 67-8). Finally, the less direct forms of evidence (such as the degree of preservation, absence of animal gnawing on the faunal material, and the presence of in situ knapping scatters) cited by several authors are ambiguous and open to reinterpretation. As a result, over 60 years since the original excavations, there is still little agreement as to either the depositional context or character of the largest assemblage of Mesolithic bone and antler artefacts from the British Isles.

\section{RESOLVING THE ENVIRONMENTAL CONTEXT OF DEPOSITION}

It was partly to resolve this issue that a new programme of fieldwork was carried out at the site between 2004 and 2015 (Conneller et al. 2012; Milner et al. in press). This work began with the excavation of several new trenches through the lake edge deposits (SC22, SC24, and SC33) and on the Mesolithic dry ground (SC23), whilst two older trenches (Cutting II \& VP85A) were re-excavated and partially extended (Fig. 2). An auger survey was also carried out (at $10 \mathrm{~m}$ intervals) to map the basal topography of the area. Larger excavations were then carried out along $55 \mathrm{~m}$ of the former lake shore, encompassing the area investigated by Clark and the subsequent interventions at the site (Fig. 2) (Milner et al. in press).

In 2015, during this work, a dense deposit of animal bone, antler, osseous artefacts (including barbed points and red deer antler frontlets), worked flint, and wood was recorded from the base of the unexcavated baulk between Clark's Cuttings I and II, and the deposits immediately to the south of Clark's excavations (Fig. 3). The character and location of this material make it likely that it represents a continuation of the assemblage observed by Clark and, as such, provides an opportunity to resolve the debates surrounding its deposition. To this end, plant macrofossil analysis was carried on samples taken from within the baulk (P3502) and the results tied into environmental profiles that been recorded from the section of Cutting II (Profile CII/2010) and trench VP85A (Profile VP85A/2010) (Fig. 2). Together, these provide a record of the local environment within which the assemblage was deposited.

The dating of the lake-edge environmental sequences and the archaeological assemblage derive from a site-wide Bayesian chronological model, constructed in OxCal v4.2, which combines 223 radiocarbon dates from the site with the relative dating sequence provided by the archaeological and sedimentary stratigraphy (Milner et al. in press). The exact details of the model can be found in Bayliss et al. (in press).

The relationship between the material recorded by Clark and the 2015 assemblage has been established using spatial data from the original publications. Clark plotted most of the bone, antler, and flint tools onto site plans, whilst part of the assemblage from Cuttings I and II were projected onto section drawings (Clark 1949, pl. viii; 1954, figs. 2, 5, \& 9-14). In addition, the height of most of the antler points in relation to the basal geology were recorded (Clark 1954, 126, table 17).

During the 2010 excavations a discrepancy of $0.13 \mathrm{~m}$ was observed with the levels cited by Mellars and Dark (1998) for the base of the environmental 
B. Taylor et al. RESOLVING THE ISSUE OF ARTEFACT DEPOSITION AT STAR CARR

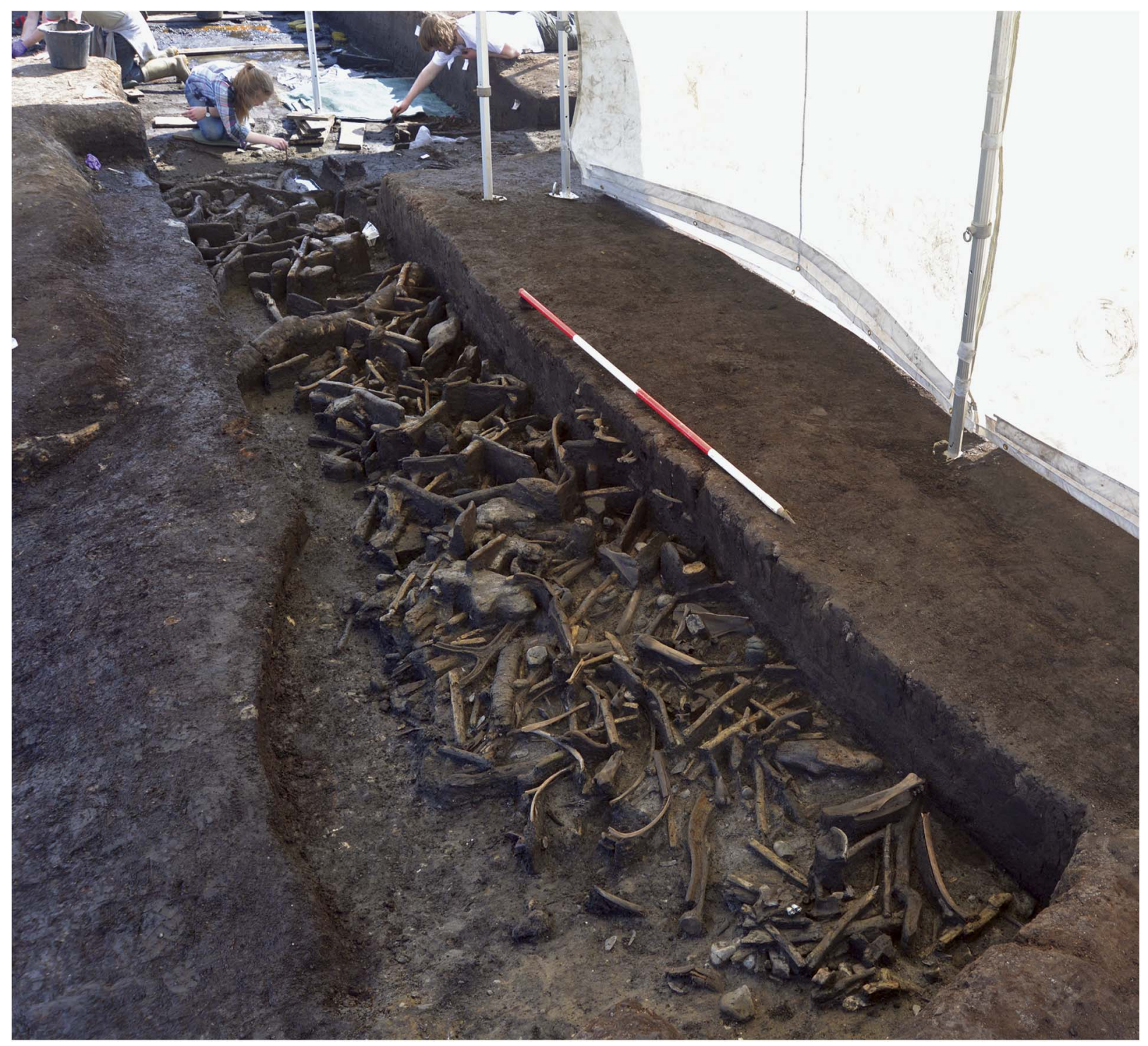

Fig. 3.

The 2015 assemblage from Clark's baulk (looking south)

profile M1. As this lay directly over the basal gravel it could not be the result of subsequent peat shrinkage. The measurement was checked using both a survey grade D-GPS on site, and a traverse using a total station from a nearby Ordnance Survey bench-mark. Both showed the current site survey to be correct, and all heights cited by Mellars and Dark (1998) have been adjusted accordingly.

Drawing the results of this work together with the analysis of the assemblage itself, and a reassessment of the material recorded by Clark, it is now possible to present a more certain account of the environmental context of the material and the modes through which it was deposited.

\section{THE 2015 ASSEMBLAGE}

The assemblage is made up of 770 pieces of worked flint, 519 fragments of animal bone, 40 pieces of antler, and large quantities of wood, along with a smaller number of bone and antler artefacts. Most of the material lay in a dense concentration towards the north of the baulk (accounting for just over half of the 
animal bone and three quarters of the flint), with a more diffuse scatter to the south of Clark's Cuttings I and III (Fig. 4). Only the lower c. 350-400 mm of the baulk survived, the upper deposits having been truncated (probably during the original excavation of Cutting II). However, the artefacts and faunal remains all lay within the basal $250 \mathrm{~mm}$ of the surviving deposits, making it unlikely that the assemblage itself had been truncated.

As with Clark's excavations the faunal material from 2015 consists mostly of the remains of larger mammals (notably red deer, but also roe deer, elk, and aurochs), with a suite of smaller mammals and birds represented by very low quantities of bone. Much of the assemblage had been generated through the butchery and subsequent processing of the carcasses of these animals, with evidence for modifications (notably spiral fractures, percussion breaks, and cut marks) on over half of the fragments, and signs of working on all of the antler. For the larger mammals there is little indication that particular parts of the body are under-represented, and the overall character of the assemblage is consistent with the butchery of complete animals. The flint was dominated by tools and utilised flakes and blades with macroscopic edge damage (forming almost half the assemblage in the baulk and a third of the assemblage in the area to the south). Scrapers and burins were the most common tool type, with a range of other types present in smaller quantities, a pattern also observed by Clark in Cutting I (Clark 1949, 57). Small debitage and burnt flint were extremely rare and mostly confined to the shorewards and uppermost layers, indicating that this assemblage was not generated through in situ flint knapping. In addition to the faunal and lithic assemblages were 29 artefacts of bone and antler; 20 barbed antler points, seven antler frontlets or masks, an elk metapodial bodkin, and a utilised fragment of an aurochs metatarsal. These occurred in similar proportions to the artefacts recorded by Clark (notably the higher numbers of barbed points and frontlets), and are closely comparable in terms of their form and manufacture.

A large quantity of wood was also present throughout the area, consisting mostly of roundwood (some with wood-working traces), but also smaller quantities of split timbers, wood chips, and artefacts (including two stakes, several digging sticks, and two hafts or handles). Crucially, none of the wood formed any sort of structural arrangement, such as pieces laid parallel to form a surface, or showed any evidence for forming a framework over which bark or hides could be placed.
Instead, the wood was interspersed amongst the other objects and materials, and represented waste from wood-working activities, tasks which had presumably been carried out on the dryland areas of the site.

The Bayesian model estimates that the assemblage began to form in $9125-9090$ cal BC $(4 \%$ probability; start Clark area; Bayliss et al. in press, fig. 17.15) or $8915-8775$ cal BC (91\% probability), probably in $8850-8800 \mathrm{cal} B C(68 \%$ probability), and that the latest material was deposited in 9100-9075 $\mathrm{cal} \mathrm{BC}(3 \%$ probability; end Clark area; Bayliss et al. in press, fig. $17.15)$ or $8830-8710$ cal $B C \quad(92 \%$ probability), probably in $8810-8755 \mathrm{cal} B \mathrm{BC}(68 \%$ probability). It spans a period of 1-145 years (95\% probability; use Clark area; Bayliss et al. in press, fig. 17.19), probably $1-65$ years $(68 \%$ probability). It is clear from the shape of the posterior distribution (Bayliss et al. in press, fig. 17.19), however, that a very short duration is probable. The radiocarbon dates on the artefacts from the assemblage form a tight group, 11 out of 12 being statistically consistent. This is compatible with these 11 artefacts being of exactly the same calendar date - potentially deriving from a single episode of deposition in which over $90 \%$ of the material was deposited (with a small number of artefacts being deposited over the following decades).

There is no indication that comparable assemblages of material extended further to the east of Clark's excavations. The re-excavation and extension of Cutting II in 2010, and excavation of the area to the east in 2013, recorded a single barbed point (at the eastern edge of Cutting II), no other bone or antler artefacts (though these were present in other parts of the site), and very small quantities of animal bone and antler. Worked flint was recorded immediately to the east of Cutting II in 2010 and 2013, but occurred higher in the stratigraphic sequence, reflecting later episodes of activity. Given that the baulk had been truncated, material from these later phases of activity may have originally extended into this area.

\section{The relationship with Clark's assemblage}

The material recorded in 2015 is clearly part of the assemblage recorded by Clark. Not only do they both consist of similar types of material and a comparable range of artefacts but they have a clear spatial relationship. In terms of its horizontal distribution both assemblages show a similar pattern. The higher density of material at the northern end of the baulk 
B. Taylor et al. RESOLVING THE ISSUE OF ARTEFACT DEPOSITION AT STAR CARR

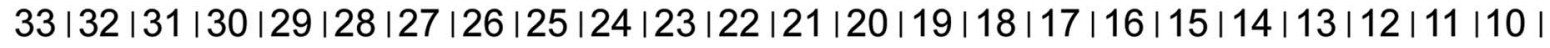

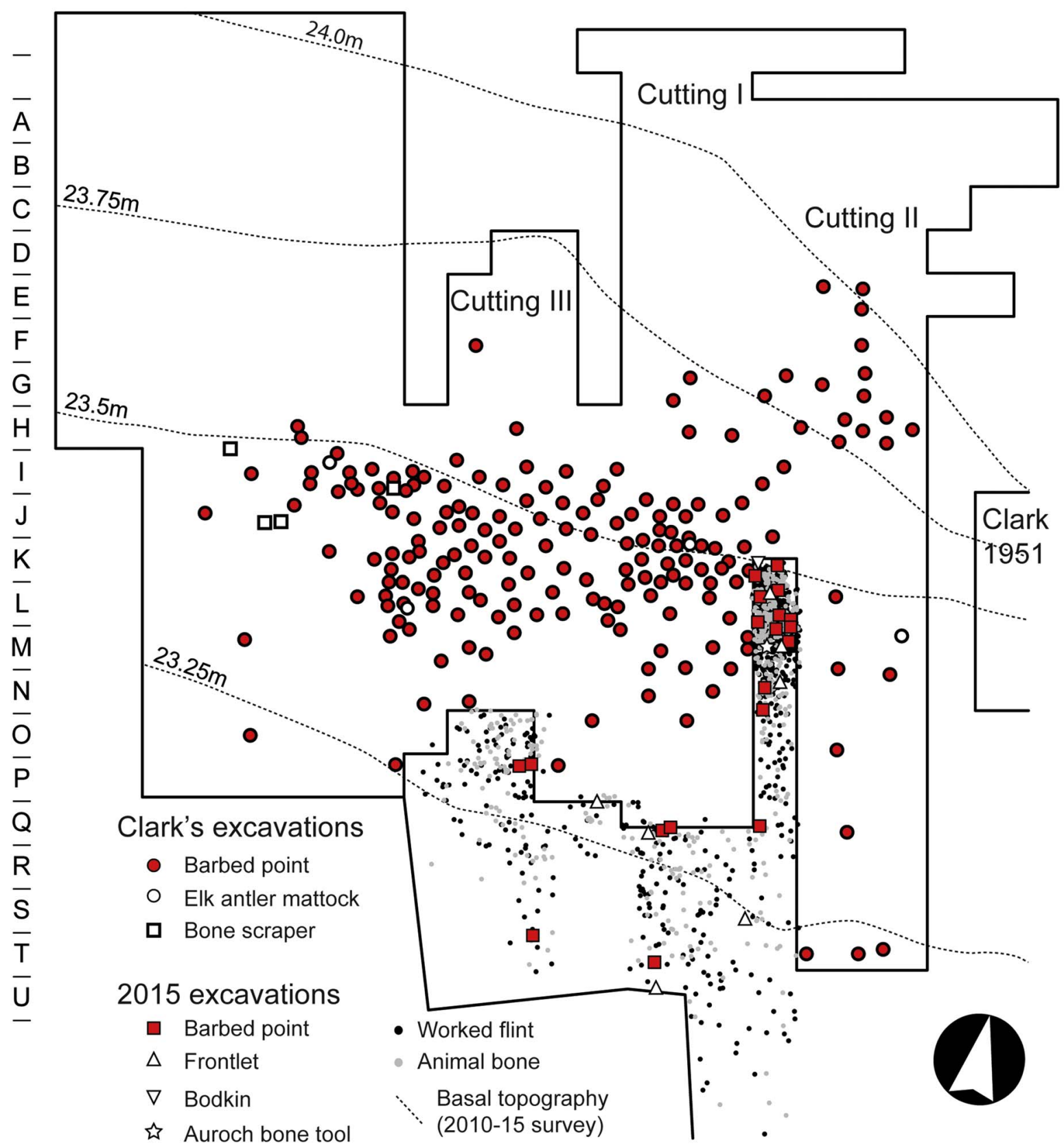

Fig. 4.

Location of barbed points \& other bone \& antler artefacts in Clark's excavations, \& the spatial distribution of the 2015 assemblage

corresponds with the greatest concentration of barbed points in the adjacent parts of Cutting I (Fig. 4) and the areas of highest flint density (Clark 1954, 6 fig. 4).
The vertical range of the assemblages is also the same. The 2015 assemblage lay within $250 \mathrm{~mm}$ of the basal sands and gravels. In Clark's Cutting I, all of 
North

South

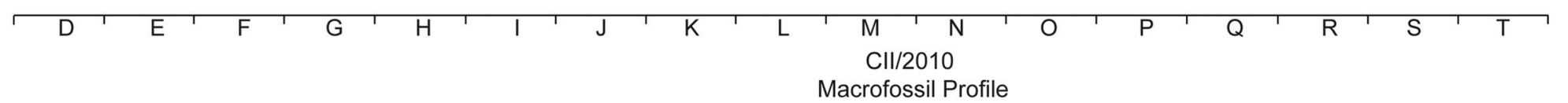

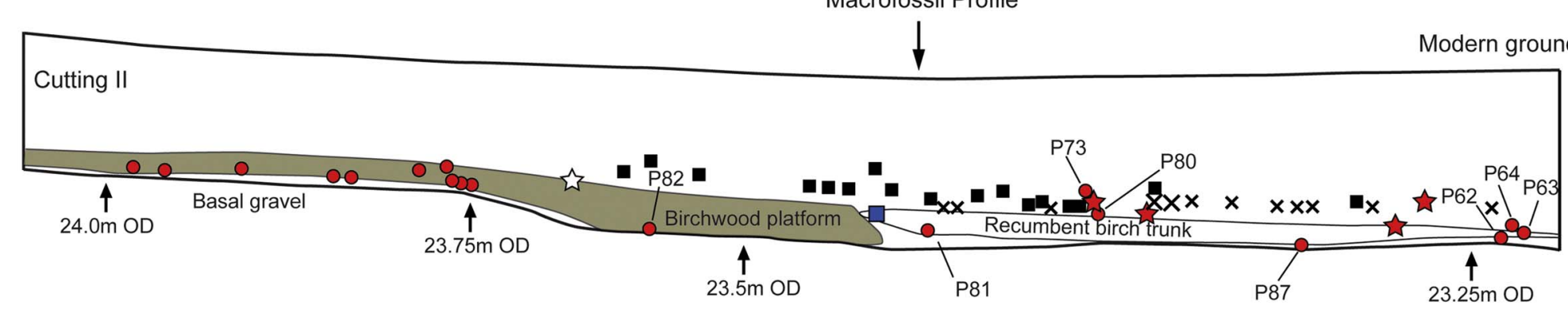

- Barbed point $\hat{\sim}$ Elk antler frontlet Upper limit of flint

Antler frontlet $\square$ Bone/antler tools $\times$ Upper limit of bone
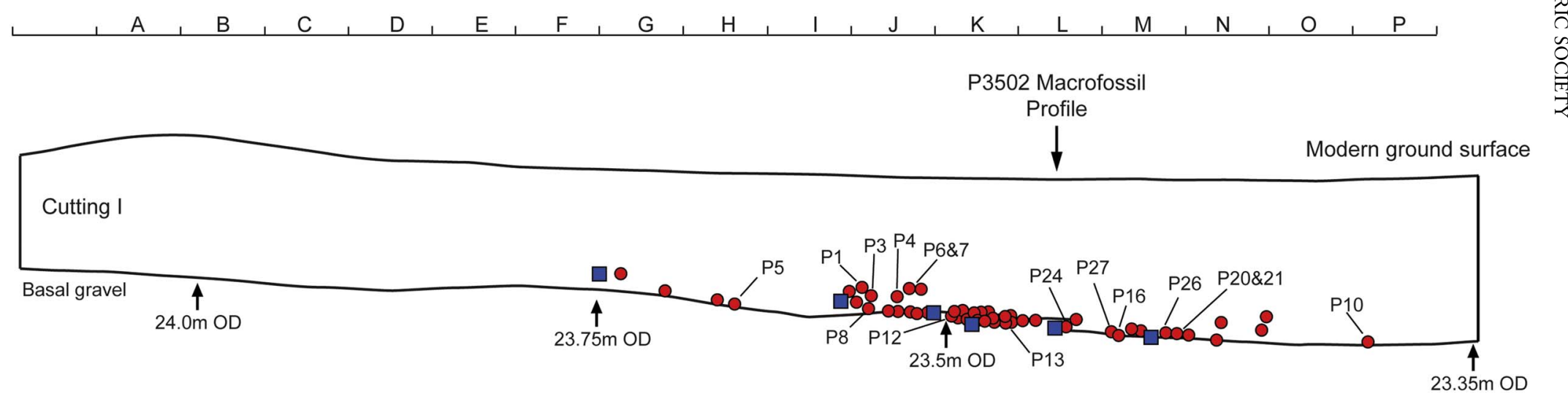

Fig. 5 .

The vertical distribution of selected artefact types in Clark's Cutting II (top) and Cutting I (bottom). After Clark (1949, pl. viii \& 1954, 3 fig. 2 
TABLE 1: BARBED ANTLER POINTS WITH HEIGHTS ABOVE THE BASAL GRAVEL RECORDED BY CLARK (1954)

\begin{tabular}{lcc}
\hline Barbed point & $\begin{array}{c}\text { Height above } \\
\text { basal gravel }(\mathrm{cm})\end{array}$ & $\begin{array}{c}\text { Height range } \\
(\mathrm{m} \text { OD })\end{array}$ \\
\hline 8 & $<6.1$ & $25.5-25.561$ \\
10 & $<6.1$ & $23.35-23.411$ \\
16 & $<6.1$ & $23.4-23.461$ \\
20 & $<6.1$ & $23.4-23.461$ \\
21 & $<6.1$ & $23.4-23.461$ \\
24 & $<6.1$ & $23.45-23.511$ \\
26 & $<6.1$ & $23.4-23.461$ \\
27 & $<6.1$ & $23.4-23.461$ \\
62 & $<6.1$ & $23.25-23.311$ \\
87 & $<6.1$ & $23.35-23.411$ \\
62 & $6.1-15.2$ & $23.311-23.402$ \\
63 & $6.1-15.2$ & $23.311-23.402$ \\
64 & $6.1-15.2$ & $23.311-23.402$ \\
4 & $6.1-15.2$ & $23.611-23.702$ \\
12 & $6.1-15.2$ & $23.561-23.652$ \\
13 & $6.1-15.2$ & $23.561-23.652$ \\
3 & $15.2-24.3$ & $23.702-23.793$ \\
81 & $15.2-24.3$ & $23.602-23.693$ \\
1 & $24.3+$ & 23.793 or higher \\
6 & $24.3+$ & 23.793 or higher \\
7 & $24.3+$ & 23.793 or higher \\
73 & $24.3+$ & 23.643 or higher \\
80 & $24.3+$ & 23.643 or higher \\
\hline
\end{tabular}

the numbered barbed points at the southern end of the trench (Grids L-O) lie less than $61 \mathrm{~mm}$ above the basal gravel, whilst the majority from the denser concentration to the north (Grids J-K) lie within $152 \mathrm{~mm}$ (Fig. $5 \&$ Table 1 ). Only points 1,6 , and 7 are more than $243 \mathrm{~mm}$ above the base of the trench, and these do not appear to be significantly higher than point 4 and 3, which have a maximum upper range of $152 \mathrm{~mm}$ and $243 \mathrm{~mm}$ respectively.

Assuming that the positions of the numbered barbed points relative to other artefacts on Clark's sections is an accurate representation of their true spatial relationships, then most of the remaining artefacts also lay on or close to the basal gravel, including the unnumbered barbed points, several bone and antler artefacts, and one of the amber beads. Whilst there are no data for the worked flint and the unworked animal bone, Clark states $(1949,56)$ that the material culture was limited to the 'bottom few inches of the peat', and that 'the general level of the occupation debris is well brought out by projecting spot-levels of the outstanding finds onto a scale drawing of the eastern face of the cutting'. This suggests that the flint and faunal assemblages in
Cutting I had a similar vertical range to the barbed points and other artefacts.

Within Cutting II, five of the seven numbered barbed points from the southern half of the trench also lie within $243 \mathrm{~mm}$ of the basal gravel, with only points 73 and 80 occurring above this (Fig. $5 \&$ Table 1). Clark also recorded the upper vertical limit of the flint and animal bone in this trench, which lies at the same level as the two higher barbed points and several other artefacts. Assuming the relationship between the bone and flint, and the two barbed points is correct, this material is more than $243 \mathrm{~mm}$ above the basal gravel. As such, it may represent a separate, later episode of deposition than the material in Cutting I and the 2015 assemblage, equivalent to the scatter of flint recorded relatively high in the profile in the 2010 re-excavation of Cutting II, and the excavations to the east of Cutting II in 2013.

\section{THE ENVIRONMENTAL CONTEXT OF DEPOSITION}

In order to establish the depositional environment of the assemblages, plant macrofossil samples were taken from the sediments within the baulk (Profile 3502) and from the section of Clarks Cutting II (Profiles CII/ 2010). Samples were also taken from the section of trench VP85A (profile VP85A/2010), immediately adjacent to Dark's Profile M1, to tie the results of the current study into the pollen and macrofossil analyses undertaken by Dark (Fig. 2). In each case a contiguous sequence of bulk samples, $25-50 \mathrm{~mm}$ thick, was taken on site. These were sub-sampled $(50 \mathrm{ml})$, disaggregated in $10 \%$ Sodium Hydroxide, and washed through nested sieves $(2 \mathrm{~mm}-125 \mu \mathrm{m})$. Each sieve fraction down to $125 \mu \mathrm{m}$ was analysed under a Zeiss Stemi DV4 stereo microscope. All macrofossils that could be identified to a specific taxon were counted, with the exception of fragments of Nymphaea alba seed epidermis and fern sporangia, which were quantified on a scale of relative abundance. The remaining material was quantified using a scale of relative abundance so as to provide a record of the peat matrix (Aaby \& Berglund 1986, 239). Macrofossil profiles were produced using C2 version 1.6.6 (Juggins 2010) and the results plotted quantitatively as the number of macrofossils of each species per sample. Given the very detailed nature of the work carried out by Dark, no further pollen analysis has been carried out. Instead, the samples from VP85A were taken immediately adjacent to Dark's profile M1 so as to allow a direct comparison with the existing pollen and macrofossil records from the site. 


\begin{tabular}{|c|c|c|c|}
\hline $\begin{array}{l}\text { Depth m OD } \\
\text { VP85A }\end{array}$ & $\begin{array}{c}\text { Depth m OD } \\
\text { CII }\end{array}$ & $\begin{array}{c}\text { Depth m OD } \\
\text { P3502 }\end{array}$ & Description \\
\hline & $23.37-23.42$ & $23.48-23.5$ & Coarse sand with a high proportion of fine detrital mud \\
\hline 23.29-23.35 & $23.42-23.56$ & $23.5-23.62$ & $\begin{array}{l}\text { Fine detrital mud with a high coarse component of moncot stem/leaf } \\
\text { (inc. Phragmites) \& unidentifiable herbaceous material, with smaller } \\
\text { quantities of roundwood. }\end{array}$ \\
\hline $23.35-23.61$ & $23.56-23.87$ & $23.62-23.7+$ & $\begin{array}{l}\text { Coarse reed peat of horizontally bedded monocot stem/leaf (inc. } \\
\text { Phragmites) \& unidentifiable herbaceous material. Levels of } \\
\text { preservation deteriorated in the upper half of the deposit \& the } \\
\text { quantity of unidentifiable herbaceous material increased. Large } \\
\text { quantities of roundwood were recorded in the lower half of this } \\
\text { deposit in Cutting II. }\end{array}$ \\
\hline 23.61-23.71 & $23.87-23.96$ & & $\begin{array}{l}\text { Coarse herbaceous detritus made up of unidentifiable herbaceous plant } \\
\text { material (some forming thin layers \& inc. Phragmites stem/leaf), } \\
\text { Cladium rhizomes, \& smaller quantities of woody detritus \& } \\
\text { roundwood. }\end{array}$ \\
\hline $23.71-23.93$ & $23.96-24.09$ & & $\begin{array}{l}\text { Coarse wood peat made up of horizontally bedded aerial roundwood } \\
\& \text { rootwood, unidentifiable woody detritus } \& \text { smaller quantities of } \\
\text { unidentifiable herbaceous material. }\end{array}$ \\
\hline
\end{tabular}

\section{Plant macrofossil results}

The macrofossil profiles from Trenches VP85A and CII have been divided into three zones based on the composition of the assemblage, which in turn reflect changes in the character of the local environment (Fig. 6a). The dates for the transitions between these zones have been established for both profiles as part of the wider programme of dating at the site (Bayliss et al. in press). Profile 3502, which was taken from the baulk between Cuttings I and II, derives from a shorter sequence of sediment and corresponds to Zone 1 and the base of Zone 2 in the more complete profiles (Fig. 6b).

Zone 1: permanently submerged reedswamp: The abundance of monocot stem and leaf in the sediments, and the consistent levels of aquatic macrofossils in all of the profiles indicates that sedimentation began at each of the sampling points in permanent standing water with emergent vegetation growing in situ. The chronological modelling indicates that the onset of organic sedimentation was uneven across the site with deposits forming first around Cutting II from 94459255 cal BC $195 \%$ probability; onset organics CII; Bayliss et al. in press, fig. 17.9), probably from 9395$9310 \mathrm{cal} B C$ (68\% probability), and later around VP85A, from 9245-8970 cal BC $(95 \%$ probability; onset organics M1; Bayliss et al. in press, fig. 17.4), probably from $9185-9015 \mathrm{cal} \mathrm{BC}(68 \%$ probability).
Phragmites reeds were growing locally throughout this zone, given the presence of its tissue within the sediments. However, a suite of other emergent plants were also present in the area, notably Scirpus lacustris (club-rush), and species of Carex (sedge) and Typha (bur-reed), the latter probably T. latifolia based on the presence of its pollen in Dark's profiles (Dark 1998, 128 fig. 11.2b). Aquatic plants are also well represented in the assemblage and may have been present in the vicinity, though seeds of Nymphaea alba (white water-lily), and oospores of Characeae (stonewort) are highly dispersive, and the parent communities may have been growing some distance away (eg, Zhao et al. 2006; Koff \& Vandel 2008). The terrestrial macrofossils are dominated the remains of Betula sp. (birch), and P. tremula (aspen) and have probably derived from trees growing at the lake shore.

From the modern habitat preference of the emergent species it is likely that the sampling points lay in water less than $1.2 \mathrm{~m}$ deep. Though Phragmites can tolerate a range of water depths (eg, Haslam 1970), the plant grows best in c. $0.5 \mathrm{~m}$ of water (Rodwell 1995, 142), though optimal growing conditions in lakes can occur in deeper water (up to $1.2 \mathrm{~m}$; Haslam 1970, 874 table 5). The presence of $T$. latifolia, would suggest that conditions at Star Carr lay at the shallower end of this range, as the plant is usually found is water less than c. $0.5 \mathrm{~m}$ deep (Preston \& Croft 1997, 324), whilst mixed communities of Phragmites and Typha form in 


\section{B. Taylor et al. RESOLVING THE ISSUE OF ARTEFACT DEPOSITION AT STAR CARR}

up to $0.6 \mathrm{~m}$ of water (Rodwell 1995, 185). This depth of water is also be compatible with the local presence of Scirpus lacustris, which grows in water between $0.3 \mathrm{~m}$ and $1.5 \mathrm{~m}$ deep (Preston \& Croft 1997, 270). It should be noted that whilst Phragmites can grow on soils that lie above the local water-table, the consistent presence of a wide range of aquatic and emergent plant macrofossils in consecutive samples in all three of the profiles would strongly suggest that all of the sampling points lay beneath the level of the lake throughout this zone.

Zone 2: Shallow water reedswamp: The reduction in the quantity of aquatic macrofossils at each of the sampling points reflects the transition to a shallower environment, which both limited the local growth of the aquatic communities and reduced the quantity of aquatic material being transported from the surrounding area. This also limited the source area of the profiles, resulting in the reduced levels of terrestrial macrofossils and the decline in species diversity. The timing of this transition was uneven, starting at CII/2010 from 9150-8930 cal BC (95\% probability; start seasonal flooding CII; Bayliss et al. in press, fig. 17.9), probably from 9080-9005 cal BC $(68 \%$ probability), and then at VP85A, from 9020-8845 cal $B C$ (95\% probability; start seasonal flooding M1; Bayliss et al. in press, fig. 17.4), probably from 89858900 cal BC (68\% probability).

Phragmites continued to grow around the sampling points, depositing stems and leaves into the sediments. However, the increasing quantities of Cladium (saw sedge) in Profiles 3502 and VP85A/2010, as well as the presence of its rhizomes within the peat suggests the plant began to colonise the area, probably in response to the shallower environment. Based on the habitat preferences of Cladium, the depth of water around the sampling points would not have been higher than $0.4 \mathrm{~m}$ (Conway 1942, 212), and was probably less. However, the ongoing decline in the quantity of aquatic material suggests that the depth of water fell throughout the zone, probably becoming seasonally submerged.

Zone 3: Terrestrial fen and carr: The absence of aquatic material from the matrix of the peat, and the paucity of aquatic macrofossils recorded in the samples, indicate that the deposits were forming beyond the reach of the water from the start of this zone. This more terrestrial environment occurred first in the area around VP85A, forming from $8790-8585 \mathrm{cal}$ BC $(95 \%$ probability; onset fen carr M1; Bayliss et al. in press, fig. 17.9), probably from $8745-8635$ cal $B C(68 \%$ probability), and then at Cutting II from 8500-8210 cal BC $(95 \%$ probability; onset fen carr CII; Bayliss et al. in press, fig. 17.4), probably from 8380-8265 cal $B C(68 \%$ probability).

The local water-table remained high, however, given the continued presence of Cladium, which grows poorly when the water-table falls below c. $0.1 \mathrm{~m}$ from the ground surface (Conway 1942, 212). What is more, the occasional presence of aquatic material suggests that the deposits were still subjected to occasional flooding. This trend towards a more terrestrial environment allowed fen species, notably Eupatorium (hemp agrimony), to expand further across the site. The increased levels of sporangia suggest that ferns were colonising large parts of the site. These are likely to have been Thelypteris palustris (marsh fern), given the sharp rise in their spores in the profiles recorded by Dark (1998, 127 fig. 11.1b). By the top of the zone, trees were probably growing in the vicinity of all of the sampling points, with fen vegetation gradually giving way to reedswamp further to the south of the excavated areas.

\section{Comparison with previous environmental work}

Overall, the macrofossil analysis is in broad agreement with the previous environmental studies from the site, both in terms of the range of species present and their change through time. All of the studies describe the same broad environmental sequence, where reedswamp in shallow standing water is succeeded by increasingly terrestrialised fen and carr environments (Cloutman \& Smith 1988, 48; Dark 1998, 158). These changes were probably driven by the accumulation of organic sediments, which caused the depth of water to become shallower leading to the development of increasingly terrestrialised conditions, a process known as hydroseral succession (eg, Birks \& Birks 1980, 59).

In terms of the specific records, the plant macrofossil profiles recorded by Dark show a very similar pattern to the current study, with a decline in the remains of arboreal and aquatic plants in the lower third of the profiles, after which species diversity declines slightly and wetland plants suited to relatively shallower or drier environments (notably Cladium) become more prominent (Dark 1998, fig. 11.4b \& 11.19). The main difference is the point at which 


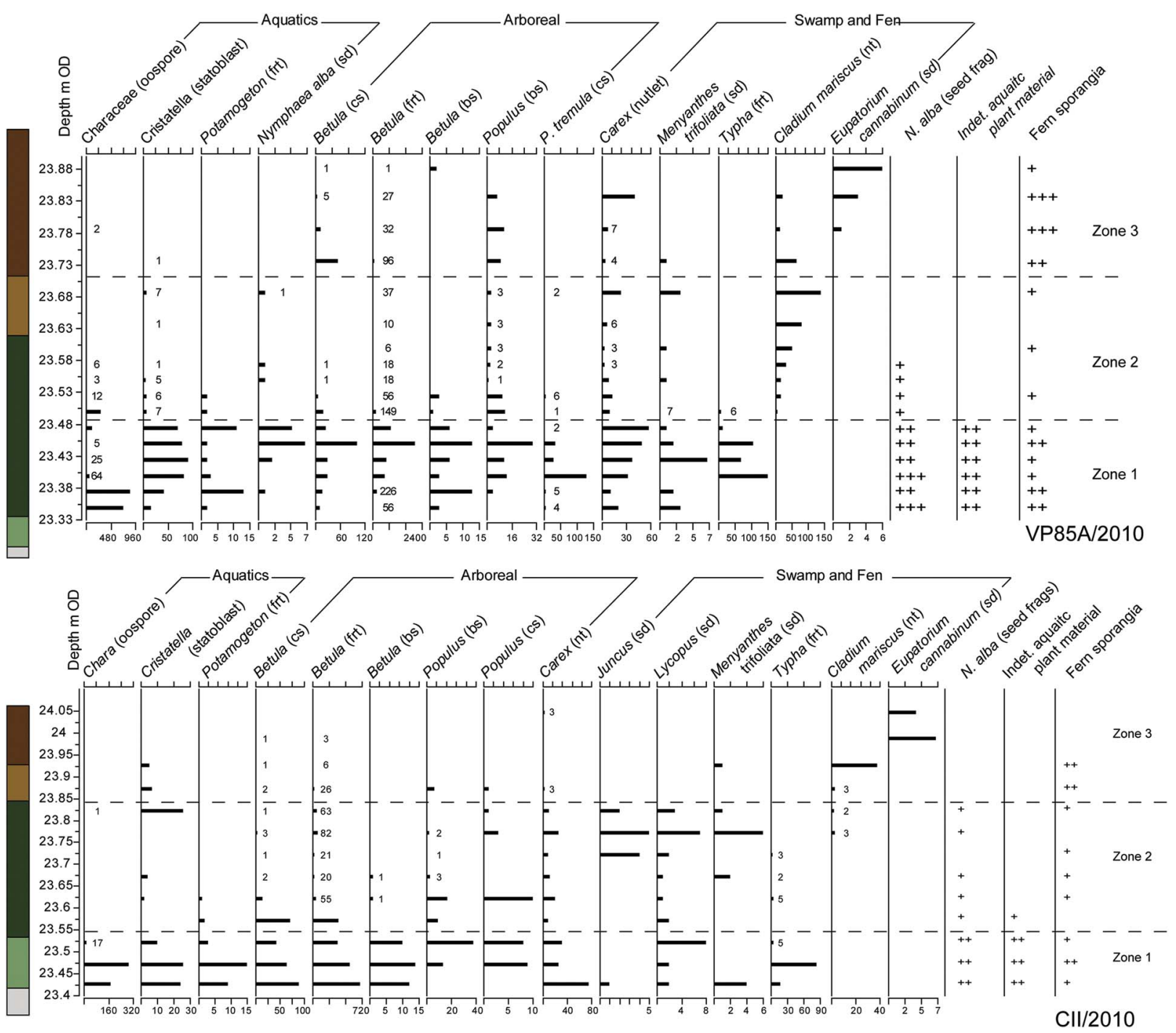

Fig. 6a.

Selected macrofossils from VP85A/2010 \& CII/2010

aquatic macrofossils disappear. In Dark's profile M1 from VP85A, aquatic material is entirely absent above the first $c .0 .2 \mathrm{~m}$ of the profile (c. $23.48 \mathrm{~m} \mathrm{OD})$, leading to her to conclude that the deposits had begun to form above the level of the lake (Dark 1998, 131 and see fig. 11.4b), whilst in the current study it declines from this point but persists till c. $23.71 \mathrm{~m}$ OD (Fig. 6a). This difference is likely to reflect the much smaller volume of material analysed by Dark, which has failed to detect the continued presence of low levels of aquatic material in the peat (see also Taylor 2011, 75). There are some slight differences in the quantities of macrofossils, notably the distinct rise and peak in Cladium, and the rise in Eupatorium noted in Zones 2 and 3 respectively. Again, these occur in lower quantities in Dark's study, which probably reflects the smaller volume of the samples.

The pollen profiles recorded by both Dark, and Cloutman and Smith are also in broad agreement with the current study. In particular, high levels of Poaceae/ Gramineae (grass) in the pollen profiles recorded at the site (Cloutman \& Smith 1988, 45; Dark 1998, 127) correspond with the abundance of Phragmites tissue within the peat. Similarly, the increasing levels of 


\section{B. Taylor et al. RESOLVING THE ISSUE OF ARTEFACT DEPOSITION AT STAR CARR}

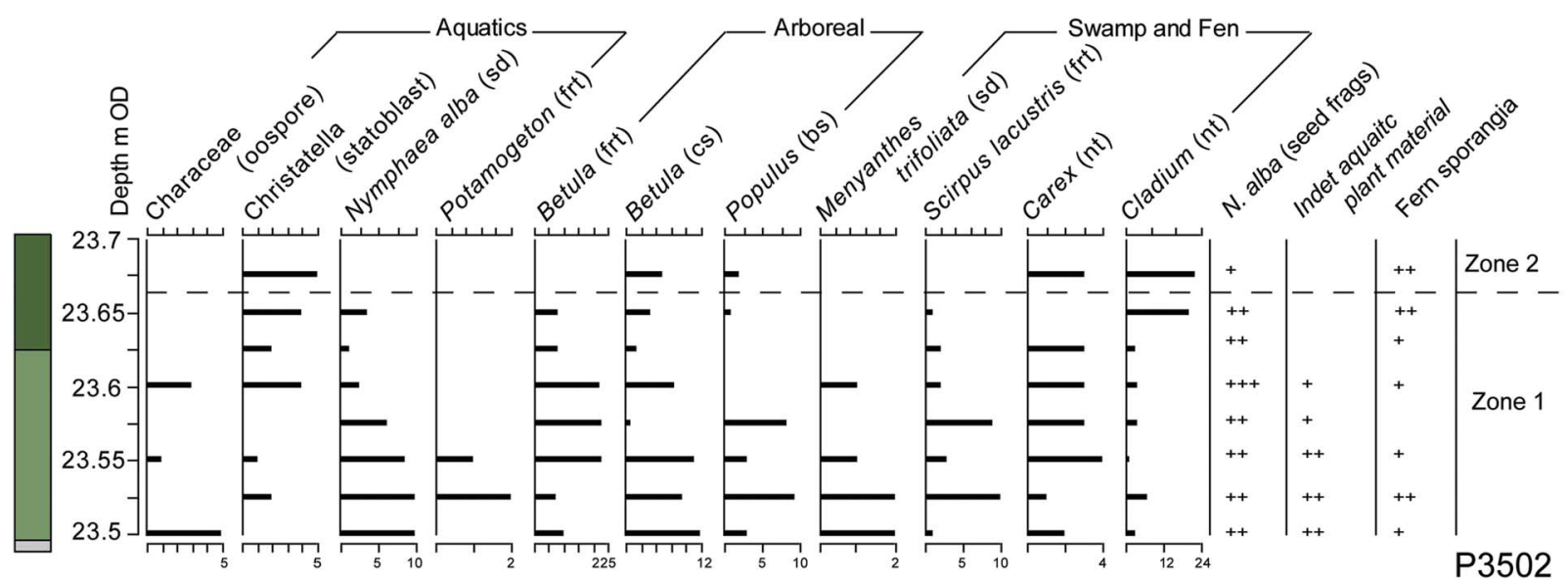

Fig. $6 b$.

Selected macrofossils from P3502

Cladium pollen reported by Cloutman and Smith (1988, figs. 5 \& 6) and Cyperaceae pollen recorded by Dark (1998, fig. 11.1a) corresponds stratigraphically with the increase in Cladium macrofossils in VP85A, whilst the rise in fern spores matches the increase in sporangia.

\section{Correlating the archaeological and environmental data}

Spatially, the 2015 assemblage and the majority of the material recorded by Clark lie within the vertical range of Macrofossil Zone 1 in both Profile 3502 and CII/ 2010. However, the Bayesian model indicates that the assemblage post-dates this zone, and that deposition occurred in the very early stages of Macrofossil Zone 2 after which the material must have sunk into the lower deposits.

The scatter of flint recorded to the east of Cutting II in 2010 and 2013 spans the transition between Zones 2 and 3, indicating deposition into the wetlands during final (drier) phases of the Cladium swamp and the terrestrialised fen. The upper range of animal bone and worked flint, recorded by Clark in Cutting II, probably also belongs to this phase of activity.

\section{The depositional environment of the Clark assemblage}

On the basis of the current study, by the time organic sediments had begun to form in the area around
Cutting II, a species-rich reedswamp was forming in shallow standing water along the lake edge (Macrofossil Zone 1) (Fig. 7). Assuming a depth of water of c. $0.5 \mathrm{~m}$ over the $\mathrm{CII}$ and $\mathrm{P} 3502$ sampling points, the level of the lake would have been $c .24 \mathrm{~m}$ OD. This would place most of the area excavated by Clark beneath the surface of the lake with the southern half of the trenches under $c .0 .5 \mathrm{~m}$ of water or more. Trees were growing at the lake edge, at the very northern end of Clark's excavations, and aquatic plants may have been present in deeper water beyond the southern end of Cutting II.

In the following centuries, as organic sediments continued to accumulate, conditions around the lake edge became shallower and the composition of the local wetland environments began to change (Macrofossil Zone 2) (Fig. 7). The area investigated by Clark now lay in no more than $0.4 \mathrm{~m}$ of water (possibly slightly less). However, as the shift to shallower conditions was probably driven by the buildup of sediments, and not a fall in water level, the overall level of the lake would have remained the same. Reedswamp environments probably persisted in the area, though Cladium had begun to replace Phragmites as the main plant community.

It was into this environment that the large assemblage of animal bone, antler, flint, wood, and osseous material culture was deposited, either in a single event or over a short period of time. There is no evidence that this material originally lay on top of a platform or occupation surface that kept it above the level of the lake. Instead, the assemblage lay directly on the peat, 

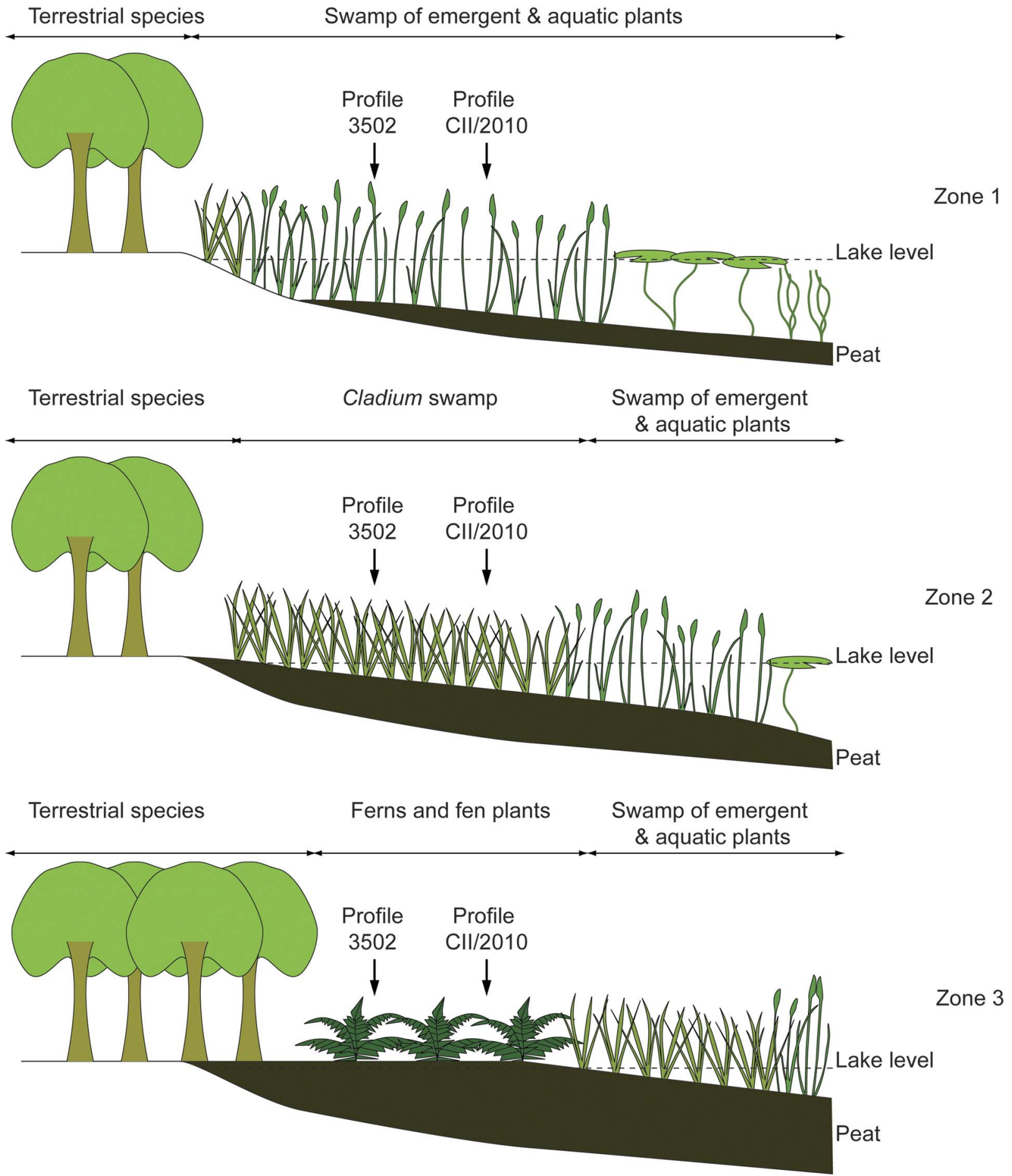

Fig. 7.

Schematic representation of the development of the lake edge environments in the area of Clark's excavations (not to scale) 


\section{B. Taylor et al. RESOLVING THE ISSUE OF ARTEFACT DEPOSITION AT STAR CARR}

in shallow standing water, before subsequently sinking through the soft wetland sediments, coming to rest on, or just above the basal gravel.

Peat continued to accumulate in this area after the deposition of the assemblage, causing the lake edge environments to become increasingly shallow. By c. 8300 cal $\mathrm{BC}$ (onset fen carr CII; Bayliss et al. in press, fig. 17.4) the deposits in the area around Clark's excavations were forming beyond the reach of the lake water, with just occasional flooding of the area (Macrofossil Zone 3) (Fig. 7). Cladium may have been present in the area, but it was now growing amongst herbs and tall fen herbs, whilst trees began to encroach onto the peat at the northern end of Clark's excavations. Ground conditions would have remained wet, with a high water-table, and the surface of the peat is likely to have been soft and boggy. It was around this time, or slightly earlier, during the latter stages of Zone 2, that worked flint and animal bone was deposited in the area of Cutting II.

\section{FORMS OF DEPOSITION IN CLARK'S ASSEMBLAGE}

Whilst the environmental context of the assemblages has been established, the question of the mode of deposition remains to be addressed. Specifically, is the material that was deposited into the shallow water swamp the result of waste disposal or more formal acts of deposition?

Focusing first on the bone and antler artefacts, we would argue that at least part of the assemblage seems to reflect a very deliberate and intentional form of deposition rather than the accidental loss that Mellars $(2009,512)$ suggests. This can be seen most clearly in the treatment of the barbed antler points. To begin with some barbed points (or the tools they were part of) were being disassembled or decommissioned prior to deposition. Both the Clark and the 2015 assemblages include barbed points that were complete (or near complete), as well as the tangs and lower portions of broken points, all of which would have originally been hafted. However, given the absence of spear or arrow shafts (either attached to the points or present within the assemblage as a whole) these barbed points must have been deliberately dehafted before being deposited. What is more, this way of treating the barbed points occurred regardless of whether they were broken beyond use (such as the broken tangs), had minor damage and could be repaired, or were largely intact.
There is also evidence for the curation of broken barbed points. A significant proportion of the points recorded by Clark (and the 2015 assemblage) were represented by the broken tips, fore-parts, or midsections. Assuming these had not been deliberately snapped before being deposited, these points had probably broken on impact whilst being used (Clark 1949, 60). As such they must have been collected from hunting sites or retrieved from the carcasses of the animal during butchery, and then deposited in the same place, and at the same time, as the dehafted barbed points.

Other objects were treated in the same way. All but one of the antler mattocks had had their haft or handle removed prior to deposition (again regardless of whether the objects were broken or relatively intact), and a flint projectile tip recorded in the 2015 assemblage had also had its haft removed. As with the barbed points, this suggests both the deliberate decommissioning of objects and the bringing together of objects in differing states of repair. This latter point is also reflected in the treatment of the red deer frontlets recorded in the 2015 assemblage, which includes examples that were unfinished (the facial bones and lower jaw had been removed, but the lower areas of the skull had not yet been trimmed away) as well as others that had been finished (and potentially utilised).

When considered together with the discrete spatial and temporal distribution of the material, this deliberate decommissioning of tools regardless of whether they could be re-used, the collection and retention of broken tips and shafts of barbed points, and the bringing together of intact and broken, or finished and unfinished, artefacts suggest that the assemblage is not simply the product of ad hoc disposal or casual loss (contra Mellars 2009, 514, and see also Chatterton 2003,72 ). Instead it suggests a very intentional form of practice, focused on specific objects that are being treated in very particular ways.

In terms of the unworked bone, antler-working waste, and worked flint, the fact that these materials were being deposited in the same part of the site, and at the same time, strongly suggests that they formed part of the same practices of deposition. Moreover, both the faunal and lithic assemblages show evidence for the curation of material prior to deposition. In the case of the animal bone, the 2015 assemblage included small, discrete clusters of material with anatomical associations, often with spiral fractures and percussion 
breaks, found in a non-articulated state in the ground. These clusters probably reflect material from discrete episodes of butchery, which has been kept together and then deposited.

Aspects of the lithic material also suggest that this assemblage has been at least partly generated through the selection of material. The very high proportion of tools and utilised pieces in the 2015 assemblage is a feature that has been recorded from wetland contexts elsewhere at Star Carr and at other sites around the lake. These cases have been interpreted as material that has been lost or discarded through tasks that were being carried out within and around the wetlands (Mellars \& Conneller 1998, 89; Conneller \& SchadlaHall 2003; Taylor 2011, 76-7). However, the quantity and density of material, particularly in the area at the northern end of the baulk, is far greater than any other assemblage from the wetland and is difficult to reconcile with the discard and loss of tools and utilised pieces through tasks carried out at this location. What is more, microwear analysis on a sample of the assemblage show that pieces were being used to work wood, bone, and hide, activities that are unlikely to have taken place within the swamp. Again, the evidence suggests the bringing together of material for deposition at this particular location.

However, not all of the lithic assemblage from this area represents acts of intentional deposition. The lithic scatter recorded at a higher level in the sequence in 2010 and 2013 by the authors, immediately to the east of Cutting II, was generated through knapping and tool production as well as tool use, and was undertaken within the terrestrialised fen and carr during the later phases of occupation at the site. This scatter continued into Cutting II, and is probably represented by the upper vertical limit of flint and bone marked by Clark on the Cutting II section drawing. Thus Mellars $(2009,507-10)$ is partly correct when he argues for in situ flint-working within the area investigated by Clark. However, this material post-dates the dense assemblage of organic artefacts, animal bone and flint that was deposited into the shallow water swamp environment, and instead reflects activity taking place in the relatively drier fen.

\section{Star Carr: a ritual site?}

Away from the area investigated by Clark there is evidence for a wide range of more prosaic tasks taking place within and around the lake-edge wetlands.
Mellars and Conneller $(1998,89)$ have noted that the flint assemblage from trench V85A (c. $20 \mathrm{~m}$ to the east of Clark's excavations) was generated through toolusing tasks that were being undertaken within the lake edge wetlands, and similar assemblages have now been recorded by the authors across much of the site (Milner et al. in press). Small quantities of worked antler and highly fragmented animal bone have also been recovered from the lake edge deposits and probably reflects the discard of material from activity areas at the adjacent shore. Moreover, the assemblage from Clark's area of the site is, essentially, the detritus of day to day practices, such as the butchery and processing of animal carcasses, the manufacture of barbed points, and the use of flint to cut and work plant materials, hide and bone.

The fact that a range of apparently prosaic activities should be taking place alongside the more deliberate forms of deposition, or that such activities are represented in the material that was being deposited, should not surprise us. As Conneller (2003, 84-5) notes, it would be a mistake to take instances of deliberate deposition as evidence of a purely 'ritual' site. Instead, the deposition of artefacts made from animal remains into the lake waters or wetland environments can be considered as culturally appropriate modes of treating this material, analogous to those noted amongst northern Eurasian hunter-gather groups more broadly (eg, Jordan 2003). At Star Carr the evidence is strongest to indicate formal deposition focused on material culture made from red deer antler, though artefacts made from other animals (such as elk antler mattocks) or butchered faunal remains and, at times, lithic artefacts were also included. However, similar forms of deposition and disposal, associated with different animal species, have been recorded at other early Mesolithic sites across north-west Europe.

On a general level, the deposition of animal bone and osseous material culture within wetland environments at early Mesolithic sites is well documented. The classic Maglemosian assemblages include sites such as Mullerup, Lundby Mose, Ulkestrup, Verup, Hohen Viecheln, Duvensee, and Friesack 4, and are concentrated within the wetland regions of northern Germany, Denmark, and southern Scandinavia (David 2005). Previous interpretations of the formation processes behind these assemblages have stressed the economic implications of their composition (Blankholm 1994), and whilst a detailed review of the contexts into which these assemblages were deposited is beyond the 


\section{B. Taylor et al. RESOLVING THE ISSUE OF ARTEFACT DEPOSITION AT STAR CARR}

scope of this paper, there some parallels within this dataset which are worth further consideration.

At the early Mesolithic site of Lundby Mose (Denmark), the butchered remains of seven elk were deposited (possibly wrapped or bound in hide) into the edge of a shallow lake (Jessen et al. 2015, 78-9). Parts of the animals had been consumed on site, whilst other parts of the carcass had been removed presumably for consumption or for use as raw materials at other locations. Hansen (2003) notes similar concentrations of elk remains on the Danish pre-Boreal sites of Skottemark and Favbro. These, along with the Lundby elk, he attributes to ritual deposition and hunting magic. Also dating to the Danish pre-Boreal Mesolithic are the whole aurochsen with microlithic lesions recovered from Vig and Prejlerups (Leduc 2014). These have been interpreted as animals that have escaped their hunters only to die from later bloodloss; however given the only animal remains from the preBoreal Mesolithic in Denmark consist of tight piles of butchered elk, and intact aurochsen, consideration should be given to suggestions these might also represent acts of formal deposition.

The selective treatment and deposition of animal remains has also been documented at Auneau in the Paris basin. In one case, this involved the removal of the facial area of an aurochs skull, which was placed in the middle of a pit on top of two horn cores, within an assemblage of butchery waste. The faunal assemblage from several other pits at the site also showed evidence for differential treatment of aurochs skulls and red deer antler (Leduc \& Verjux 2014, 44-5, 50).

A comparable episode of deposition has also been recorded in the Star Carr landscape, where parts of a butchered aurochs carcass were deposited (again possibly in a bag) into a small pond adjacent to an area of early Mesolithic settlement (Overton \& Taylor in press). Overton has also identified evidence for the selection and curation of elements from fur bearing mammals at several early Mesolithic sites in the south of England within assemblages of faunal material reflecting butchery and other economic activities (Overton 2016).

At each of these sites, the killing, butchering, and consumption of animals was followed by very deliberate forms of deposition. Whilst the motivations behind these practices may have differed, the evidence from these sites suggests that the treatment and disposal of animal remains (or objects made from them) during the early Mesolithic was structured by particular rules and traditions. Rather than seeing these as 'ritual', the fact that they often occur alongside evidence for more prosaic activities suggests that this distinction was not apparent in the past. For this reason we would conclude that all previous interpretations of the site that posit a single function for Star Carr should be rejected.

\section{CONCLUSIONS}

Analysis of the context and mode of deposition of the classic Star Carr assemblage reveals a complex picture of depositional practices, focused on different materials, and varying throughout the environmental sequence. Much of the assemblage was generated through the formal deposition of bone and antler artefacts, the butchered remains of animals, worked flint, and wood into an area of shallow standing water. As the lake edge deposits formed above the level of the lake, fen plants and trees began to grow directly on the peat, and people began to knap flint within the wetland.

The results of our work show that there was no single context of deposition at Star Carr, nor were artefacts deposited in a uniform manner or through the results of a common set of practices. Instead, the ad hoc loss and disposal of material through day to day tasks occurred alongside more structured patterns of artefact deposition suggesting that apparently ritual behaviour was in fact simply part of the daily lives of the people who inhabited Star Carr.

Acknowledgements: The excavations at Star Carr 20042015 have been funded by the British Academy (SG-44333, SG-47081, SG-50217), English Heritage/Historic England (grant numbers 5536 and 6064), NERC (NE/I015191/1), ERC (Postglacial project 283938), the Vale of Pickering Research Trust, University of Chester, University of Manchester, \& University of York, The McDonald Institute, Cambridge, \& UCL. The palaeo-environmental analysis and correlation with the archaeological material was undertaken by Taylor as part of his AHRC funded doctoral research. We would like to thank the Vale of Pickering Research Trust and English Heritage/Historic England for their continued support, the landowners, and all the students and volunteers who have participated in the excavations.

\section{BIBLIOGRAPHY}

Aaby, B. \& Berglund, B.E. 1986. Characterisation of peat and lake deposits. In B. E. Berglund (ed.), Handbook of Holocene Palaeoecology and Palaeohydrology, 231-46. Chichester: Wiley 
Bayliss, A., Taylor, B., Bronk Ramsey, C., Dunbar, E., Kromer, B., Bamforth, M., Conneller, C., Elliott, B., Knight, B. \& Milner, N. in press. Dating the archaeology and environment of the Star Carr embayment. In N. Milner, C. Conneller \& B. Taylor (eds), Star Carr, Volume 2. Studies in Technology, Subsistence and Environment York: White Rose Press

Birks, H.J.B. \& Birks, H.H. 1980. Quaternary Palaeoecology. London: Edward Arnold

Blankholm, H. P. 1994. On the Track of a Prehistoric Economy: Maglemosian subsistence in early postglacial south Scandinavia. Århus: Aarhus University Press

Chatterton, R. 2003. Star Carr reanalysed. In J. Moore \& L. Bevan (eds), Peopling the Mesolithic in a Northern Environment, 69-80. Oxford: British Archaeological Report S1157

Clark, J.G.D. 1949. A preliminary report of excavations at Star Carr, Seamer, Scarborough, Yorkshire. Proceedings of the Prehistoric Society 15, 52-69

Clark, J.G.D. 1950. A preliminary report of excavations at Star Carr, Seamer, Scarborough, Yorkshire (second season). Proceedings of the Prehistoric Society 16, 109-29

Clark, J.G.D. 1954. Excavations at Star Carr. Cambridge: Cambridge University Press

Cloutman, E. \& Smith, A.G. 1988. Palaeoenvironments in the Vale of Pickering, Part 3: Environmental history at Star Carr. Proceedings of the Prehistoric Society 54, 37-58

Conneller, C. 2003. Star Carr recontextualised. In J. Moore \& L. Bevan (eds), Peopling the Mesolithic in a Northern Environment, 81-6. Oxford: British Archaeological Report S1157

Conneller, C. 2004. Becoming deer: corporeal transformations at Star Carr. Archaeological Dialogues 11, 37-56

Conneller, C. \& Schadla-Hall, R.T. 2003. Beyond Star Carr: the Vale of Pickering in the tenth millennium вр. Proceedings of the Prehistoric Society 69, 85-105

Conneller, C., Milner, N., Taylor, B. \& Taylor, M. 2012. Substantial settlement in the European early Mesolithic: new research at Star Carr. Antiquity 86(334), 1004-20

Conway, M.V. 1942. Cladium mariscus. Journal of Ecology 30(1), 211-16

Dark, P. 1998. Palaeoecological investigations. In Mellars \& Dark (eds), 1998, 111-210

Dark, P., Higham, T.F.G., Jacobi, R. \& Lord, T. 2006. New radiocarbon accelerator dates on artefacts from the early Mesolithic site of Star Carr, North Yorkshire. Archaeometry 48(1), 185-200

David, E. 2005. Technologie osseuse des derniers chasseurs préhistoriques en Europe du Nord (Xe-VIIIe millénaires av. J.-C.). Le Meglemosien et les technocomplexes $d u$ Mésolithique. Unpublished $\mathrm{PhD}$ thesis, Masin Archéologie Ethnologie, Nanterre

Hansen, K.M. 2003. Pre-Boreal elk bones from Lundby Mose. In L. Larsson, H. Kindren, K. Knutsson, D. Loeffler \& A. Akerlund (eds), Mesolithic on the Move, 521-6. Oxford: Oxbow Books

Haslam, S.M. 1970. The performance of Phragmites communis Trin. in relation to water supply. Annals of Botany 34, 867-77
Jessen, C.A., Pedersen, K.B., Christensen, C., Olsen, J., Mortensen, M.F. \& Hansen, K.M. 2015. Early Maglemosian culture in the Preboreal landscape: Archaeology and vegetation from the earliest Mesolithic site in Denmark at Lundby Mose, Sjælland. Quaternary International 378, 73-87

Jordan, P. 2003. Material Culture and Sacred Landscape: the anthropology of the Siberian Khanty. Lanham MD: Alta Mira Press

Juggins, S. 2010. C2 1.66 Software for Ecological and Palaeoecological Data Analysis and Visualisation. https://www.staff.ncl.ac.uk/stephen.juggins/software/C2 Home.htm

Koff, T. \& Vandel, E. 2008. Spatial distribution of macrofossil assemblages in surface sediments of two small lakes in Estonia. Estonian. Journal of Ecology 57(1), 5-20

Leduc, C. 2014. A specialized Early Maglemosian site at Lundby Mose (Zealand, Denmark): a contribution to the understanding of Maglemosian patterns of animal resource exploitation. Journal of Archaeological Science 41, 199-213

Leduc, C. \& Verjux, C. 2014. Mesolithic occupation patterns at Auneau 'Le Parc du Château' (Eureet-Loire France): contribution of zooarchaeological analysis from two main pits to the understanding of type and length of occupation. Journal of Archaeological Science 47, 39-52

Legge, A. \& Rowley-Conwy, P. 1988. Star Carr Revisited: a re-analysis of the large mammals. London: Centre for Extra-Mural Studies

Mellars, P. 2009. Moonshine over Star Carr: postprocessualism, Mesolithic myths and archaeological realities. Antiquity 83, 502-17

Mellars, P. \& Conneller, C. 1998. Lithic assemblages. Mellars \& Dark (eds), 1998, 83-98

Mellars, P. \& Dark, P. 1998. Star Carr in Context: New archaeological and palaeoecological investigations at the early Mesolithic site of Star Carr, North Yorkshire. Cambridge: McDonald Institute for Archaeological Research

Milner, N., Conneller, C. \& Taylor, B. in press. Star Carr, Volume 1. A Persistent Place in a Changing World. York: White Rose University Press

Overton, N. 2016. More than skin deep: Reconsidering isolated remains of 'fur bearing species' in the British and European Mesolithic. Cambridge Journal of Archaeology 26(4), 561-78

Overton, N. \& Taylor, B. in press. Humans in the environment: plants, animals and landscapes. Journal of World Prehistory Special edition.

Preston, C.D. \& Croft, J.M. 1997. Aquatic Plants in Britain and Ireland. Colchester: Harley Book

Price, T. 1982. Willow tales and dog smoke. Quarterly Review of Archaeology 3, 4-7

Price, T.D. 1983. Annual review of Old World archaeology. The European Mesolithic. American Antiquity 48, 761-78

Rodwell, J.S. 1995. British Plant Communities Volume 4: Aquatic communities, swamps and tall herb fens. Cambridge: Cambridge University Press

Rowley-Conwy, P. 2010. From great bog fen to sedge fen. A note on Grahame Clark's interpretation of Star Carr in its landscape context. In A. Marciniak \& J. Coles (eds), 


\section{B. Taylor et al. RESOLVING THE ISSUE OF ARTEFACT DEPOSITION AT STAR CARR}

Grahame Clark and his Legacy, 68-86. Newcastle: Cambridge Scholars Publishing

Taylor, B. 2011. Early Mesolithic activity in the wetlands of the Lake Flixton Basin. Journal of Wetland Archaeology $11(1), 63-84$
Walker, D. \& Godwin, H. 1954. Lake stratigraphy, pollenanalysis and vegetational history. In Clark 1954, 25-69

Zhao, Y., Sayer, C.D., Birks, H.H., Hughes, M. \& Peglar, S.M. 2006. Spatial representation of aquatic vegetation by macrofossils and pollen in a small and shallow lake. Journal of Palaeolimnology 35, 335-50

\section{RÉSUMÉ}

Résoudre la question des dépôts d'artefacts à Star Carr, de Barry Taylor, Ben Elliott, Chantal Conneller et Nicky Milner

Depuis sa publication en 1954 Star Carr a joui d'un statut iconique au sein de l'archéologie mésolithique britannique. Les premières excavations du site ont documenté un grand assemblage d'outils en os et bois de cerf d'une séquence de dépôts tourbeux en bordure du paléo-lac de Flixton. Plus de 60 ans plus tard, il reste le plus grand assemblage d'artefacts d'os et de bois de cerf de sa datation en Grande-Bretagne et a constitué une source inestimable de renseignements sur la vie au mésolithique ancien. Toutefois, l'interprétation de ce matériel a fait l'objet d'un intense débat, et l'assemblage a été diversement décrit comme vestiges d'une occupation in situ, tas d'ordures, et résultat d'actes de dépôt culturellement prescrits. Fondamentalement, ces très différentes idées de la nature du site reposent sur des interprétations divergentes du contexte environnemental dans lequel la majorité des artefacts organiques a été déposée. Cet article présente les résultats des travaux récents à Star Carr qui contribuent à résoudre le débat entourant à la fois le contexte de l'assemblage et les motivations qui font suite à son dépôt.

\section{ZUSSAMENFASSUNG}

Eine Lösung für die Frage der Artefaktdeponierung in Star Carr, von Barry Taylor, Ben Elliott, Chantal Conneller und Nicky Milner

Seit der Publikation im Jahr 1954 hat der Fundplatz Star Carr einen „Kultstatus“ in der Archäologie zum britischen Mesolithikum inne. Die ursprünglichen Ausgrabungen dokumentierten ein großes Ensemble von Werkzeugen aus Knochen und Geweih aus einer Abfolge von Torfschichten am Rand des Paläo-Sees Lake Flixton. Auch nach mehr als 60 Jahren stellt es das größte Ensemble an Knochen- und Geweihartefakten dieser Zeitstellung in Großbritannien dar und bildet eine unschätzbare Informationsquelle für das Leben im frühen Mesolithikum. Die Interpretation dieses Fundmaterials unterlag jedoch einer intensiven Diskussion, und das Ensemble wurde wahlweise beschrieben als die Überreste einer in situ-Siedlung, als Abfallhaufen oder als Resultat kulturell vorgegebener Deponierungshandlungen. Grundsätzlich hängen diese sehr unterschiedlichen Vorstellungen über den Charakter des Fundplatzes von den verschiedenen Rekonstruktionen des ökologischen Kontextes ab, in den die Mehrzahl der organischen Artefakte deponiert worden waren. Diese Beitrag präsentiert die Ergebnisse der jüngsten Arbeit bei Star Carr, die hilft, die Debatte um den Kontext der Assemblage und die Beweggründe, die hinter seiner Ablagerung liegen, zu lösen.

\section{RESUMEN}

Resolviendo el problema de la deposición de los artefactos en Star Carr, por Barry Taylor, Ben Elliot, Chantal Conneller y Nicky Milner

Desde su publicación en 1954 Star Carr se ha convertido en un icono de la arqueología del Mesolítico británico. Las excavaciones originales en el yacimiento documentaron un gran conjunto de útiles en hueso y en asta en una secuencia de depósitos de turba en las orillas del paleolago Flixton. En los últimos 60 años continúa siendo el mayor conjunto de artefactos en hueso y asta de su cronología en Gran Bretaña, y ha constituido una fuente de información inestimable para la reconstrucción de los modos de vida en el Mesolítico inicial. Sin embargo, la interpretación de este material ha estado sometida a un intenso debate, y el conjunto ha sido descrito de forma 
variada como un asentamiento in situ, como un vertedero o como resultado de actos de deposición ordenados culturalmente. Básicamente, las distintas hipótesis sobre la naturaleza del sitio dependen de diferentes interpretaciones sobre el contexto medioambiental en el que se ha depositado la mayor parte de los artefactos orgánicos. Este artículo presenta los resultados de trabajos recientes en Star Carr que ayudan a resolver el debate que rodea tanto el contexto de la asamblea como las motivaciones que subyacen a su deposición. 